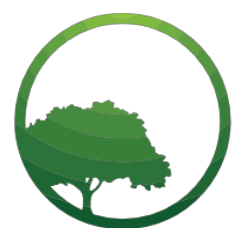

Business \& Social Science IJRBS

\section{Research in Business and Social Science}

IJRBS Vol 8 No 1, ISSN: 2147-4478

Contents available at www.ssbfnet.com/ojs

\title{
Influence of Consumer Complaints Handling on Consumer Satisfaction in Dairy Milk Processors in Kenya
}

\section{Anne Wairimu Mwangi}

Corresponding Author: Department of Business and Entrepreneurship, Karatina University, Kenya.

ORCID ID: 0000-0001-5279-8622 +254 722641254

\section{Ndung'u Kabare}

$P h D$, Department of Business and Entrepreneurship, Karatina University, Kenya.

$+254722388635$

\section{Kenneth Wanjau}

Professor, Department of Business and Entrepreneurship, Karatina University, Kenya.

$$
\text { +254722386353 }
$$

\begin{abstract}
The purpose of this study was to assess the influence of consumer complaints handling on consumer satisfaction in dairy milk processors in Kenya. The study population was 384 consumers from 15 major supermarkets chains in Kenya. Primary data was sought from consumers of processed dairy milk using a semi-structured self-administered questionnaire employing a mixed methods research design. Descriptive and regression analysis and regression analysis were conducted with the help of SPSS software. Majority of the respondents disagreed that their complaints were handled so well to their expectation. Respondents also disagreed that merchandisers were receptive to their complaints as consumers to their satisfaction. The results showed a weak positive relationship between complaints handling and consumer satisfaction. The beta value of the computed (composite index) scores of consumers' complaints handling was 0.027 with a t-test value of 1.026 and significance level of 0.306 . Dairy milk processors in Kenya had poor consumer complaints handling mechanisms. However this seemed to have no reduction in consumer satisfaction in the products in question. The study recommended that dairy milk processors in Kenya had poor consumer complaints handling mechanisms.
\end{abstract}

Key words: Consumer Complaint Handling, Consumer Satisfaction

JEL classification: M31

Submitted: 07.02.2019 - Accepted: 21.02.2019 


\section{Introduction}

A complaint is any expression of dissatisfaction by a customer, potential customer or other business partner related to a service or product Zineldin (2006). Stauss (2002) defines complaint satisfaction as "the satisfaction of a complainant with a company's response to her/his complaint". Karapetrovic (2006) defines complaints handling procedures as addressing individual complaints and compensating consumers. Priluck and Lala (2009) defines effective complaint handling as a thoughtful procedure for resolving problems and handling disgruntled consumers. This study adopted Priluck et al. (2009) definition of consumer complaints handling as a thoughtful procedure for resolving problems and handling disgruntled consumers. Globally, customer satisfaction has been a key factor in formation of customer's desires for future purchase (Mittal \& Kamakura, 2001). Complaints handling is an important part of any company. When customer service handles complaints satisfactorily, it reflects directly on how important the customers are to the company (Strauss, 2002). Many companies do not pay sufficient attention to handling complaints effectively (Stauss \& Schoeler, 2004, Homburg \& Fürst, 2007). This is surprising as customer complaints are a valuable source of important market intelligence (Priluck et al., 2009), which companies should use to correct the root cause of the problem and to improve the service or product (Mccollough, 2000).

Satisfaction is a person's feelings of pleasure or disappointment resulting from comparing a product's perceived performance (or outcome) in relation to his or her expectations (Kotler, 2003). Consumer satisfaction is, "the extent to which a product's perceived performance matches a buyer's expectations" if the performance match the customers expectation, they are satisfied and if, performance exceeds the customer's expectation then customers are highly satisfied or delighted. (Armstrong \&Kotler, 2009). This study adopted Kotler,(2003) definition, that satisfaction is a person's feelings of pleasure or disappointment resulting from comparing a product's perceived performance (or outcome) in relation to his or her expectations. Over the last decade, all sizes and types of organizations have understood the importance of customer satisfaction. Overall satisfaction has a strong positive effect on customer loyalty intentions across a wide range of product and service categories (Gustafsson, 2005). It is generally observed that, to keep a customer is less costly than to win a new one. There is a strong link between customer satisfaction, customer retention and profitability.

The dairy milk processors products are globally facing a very competitive environment that is forcing it to enhance the development and sustainability of loyalty opportunities (Davis, Dong, Blayney and Owens, 2010). Thus, keeping loyal customers represents a strategy for achieving distinct and sustainable competitive advantage (Roberts, 2003). However, there is no consensus on the determinants of customer satisfaction. As the competitive environment becomes more dynamic, the most important issue the sellers face is no longer to provide excellent, good quality products or services, but also to keep loyal consumers who will contribute long-term profits to organizations (Tseng, 2007). Globally, milk industry makes a significant contribution to the economy. Milk and milk products consumption is common throughout the world. The dynamics that affect milk production tend to differ from country to country (Nyariki \& Thirtle, 2000). Dairy milk processors have been a source of employment to many people globally. In Ethiopia the 24 processing units have created employment opportunities in rural areas, with each unit employing up to four permanent workers (Redda, 2001). In Kenya the dairy industry accounted for $4.1 \%$ of gross domestic product (GDP) and is a major source of livelihood for more than one million people in the sub-sector $(F A O, 2011)$. Currently the sector provides food, income and employment for approximately 1.8 million people across the dairy value chain: farmers, transporters, traders and 
vendors, employees of dairy societies, milk processors, input suppliers, service providers, retailers and distributors (ROK, 2010).

In terms of nutrition and food security, almost all Kenyans consume milk on a daily basis with an average per capita milk consumption of 115 litres per year (KDB, 2012). Dairy products make up the largest share of food expenditure in Kenyan household budgets (Kiatibie, Omore, Rich \& Kristjanson, 2010). Due to the importance of the dairy industry in Kenyas' growth and development it has been recognized in vision 2030 (Baiya \& Kithinji, 2010). Brookside is a market leader in Kenya's food industry, it has developed sophisticated key performance indicators to ensure consistent high production with consistent high quality (Brookeside, 2014). The company is not only focused on the volume of milk produced and sold, the company closely monitors its products for fat content and bacteria levels to ensure quality is enhanced. For quality maintenance, milk goes to cooling centers, where it is chilled to between six and seven degrees Celsius (Njarui, 2009). In Kenya, for dairy processing industries to remain competitive locally and globally they must create value by having high quality products and variety, perceived value and satisfied consumers in order to create a sustainable loyal consumer base (Karanja, 2007).

In Kenya, statistics indicate that the total milk produced and marketed increased by a paltry 4.2 percent from 402.2 million liters in 2013 to 419.1 million liters in 2014, despite there being an increased demand for milk products (RoK, 2015). Kenya Dairy Report (2015) posits that $85 \%$ of marketed milk is sold raw while $15 \%$ is sold as processed milk by dairy milk processors. This indicates that, Kenyan consumers are dissatisfied with milk processing firms despite the quality initiatives they have put in place. In a study by Ouma, Staal, Omore, Wanjohi, Njoroge and Njubi,(2000) found that consumers preferred raw milk to processed milk because they perceive raw milk to have high butter fat content, appealing taste and is affordable.

Several studies have been done about the dairy milk industry in Kenya. Several local studies concerning the milk industry have been done. Most of the studies were done on primary production stage. Tuei (2010) did a study on milk quality control and regulation in dairy production, a case of dairy production in Kikuyu Division. The study found out that to improve milk quality smallholder farms need to avail new design of tanks for small amounts of milk for transporting milk to the required destination. Mursi (2015) did a study to examine the existing supply chain management in Kenya's dairy industry using Gakindu Dairy as a case study.

The study found that dairy farmers sold their milk through the informal chain mainly because it offered higher prices and quality than the formal chain. However, fewer studies have focused on dairy milk processors (secondary production). Mwendwa (2008) did a study to establish strategic responses by Kenya milk processors to environmental challenges. It was found that firms have developed strategies to counter react to the impact of the environmental forces. Njarui, Gatheru, Wambua, Ngulu, Mwangi and Keya (2012) did a study whose objective was to understand the functioning of milk processing and marketing systems in order to identify appropriate interventions to enhance growth of the dairy industry in eastern province. They found that to remain competitive processors must diversify their products through value addition and cost effective methods. In view of the above studies, it is clear that previous studies have not provided adequate evidence on the relationship between consumer complaints handling and consumer satisfaction.

This paper therefore sought to assess the influence of consumer complaints handling on consumer satisfaction in dairy milk processors in Kenya. The paper was guided by the hypothesis stating that consumers complaints handling has no significant influence on consumer satisfaction of dairy milk processors in Kenya 


\section{Literature Review}

\section{Theoretical Review}

The Theory of Reasoned Action (TRA) assumes that behavioral intention is an important factor in determining behavior (Ajzen \& Fishbein, 1980; Fishbein \& Ajzen,1975). The TRA postulates that there are two conceptually independent determinants of behavioral intention. The first determinant is attitude toward the behavior, which refers to whether an individual has a favorable or unfavorable evaluation of the behaviour (Ajzen, 1991; Fishbein \& Ajzen, 1975). This means the consumer of dairy processed milk will either have a positive or negative perception towards buying the product. The second determinant is subjective norm which refers to the perceived social pressure to perform or not to perform a behavior (Ajzen, 1991; Fishbein \& Ajzen, 1975). The consumer of dairy processed milk can be influenced in the buying behavior by the people for whom they buy the milk i.e. the product they buy may be dictated by family members. Theory of Reasoned Action holds that, whether or not an individual performs a certain behavior can be predicted by his/her behavioral intention. The TRA, which consists of only two components (i.e. attitudes toward the behavior and subjective norms), is often criticized because it assumes that all human behaviors are volitional and rational (Chang, 1998). However, not all behaviours are full volitional or fully controlled by the individual (Ajzen, 2005). For instance, when an individual chooses to purchase a new milk brand, a number of factors may prevent him/her from making a rational decision. An individual may like the new milk brand, but he/she may purchase another milk brand because of another household member disagrees with his/her choice. In this case, an individual may change his/her intended purchasing behavior due to factors outside his/her control.

Consumers are frequently faced with judging the quality of various products, when determining what to buy, in what amount. It may, however, be difficult for consumers to assess the importance of various quality-aspects in relation to each other and in relation to requirements rooted in the intended use of the products (SOU, 1994). Therefore, consumers of dairy processed milk are often faced with uncertainty when making judgments of the quality of products. However, the consumers of dairy processed milk may neither have the time nor the motivation to engage in extensive comparisons of the considered products. According to 'cue utilization theory' (Olson \& Jacoby, 1972 ;Richardson, 1994) consumers may try to overcome their uncertainty and the lack of information by selecting one or more indicators (cues/stimuli) as a basis for their assessment of the quality of the product. An overwhelming amount of research on cue utilization theory has revealed a number of cues, which may be used by consumers as indicators of quality, including 'country-oforigin' (Eliot \& Cameron, 1994; Peterson \& Jolibert, 1995), 'product composition' (Olson, 1972), 'brand name' (Dodds, 1991), 'store name' (Dodds, 1991; Dodds, 1995), and 'price' (Leavitt, 1954; Shapiro, 1973; Brooker., 1986).

Almost all dairy processed milk products have competitors, and the quality differences among competing products may not be easily recognizable. It is difficult, if not impossible, for dairy processed milk consumers to avoid comparing competing products before selecting the product they will purchase. Consumer purchase decisions, however, "are frequently made under conditions of varying uncertainty regarding the product and its attributes" (Jacoby, Olson, \& Haddock, 1971). To overcome uncertainty consumers of dairy processed milk are likely to try and find product cues that will provide some ideas about the products in which they are interested (Akdeniz., 2013). Unfortunately, consumers of dairy processed milk faced increased uncertainty or complexity when making purchase decisions because the number of competing products is increasing as time goes by (Sullivan \& Burger,1987). Thus, manufactures of dairy processed milk have to consider how consumers process product information and assess variables such as quality and value. In 
addition, they need to make their products' cues more remarkable so that consumers will be attracted to a focal product, and have positive thoughts about product quality. Jacoby , (1971) enumerated the product cues that are utilized to form impressions of quality: (1) price, (2) product composition characteristics, (3) brand (manufacturer), (4)advertising, (5) word-of mouth reports, and (6) past purchase experience. "These cues are dichotomized as either intrinsic or extrinsic to the product" (Reimer \& Kuehn, 2005).Reimer and Kuehn (2005) explained that intrinsic cues are attributes that physically exist in the product such as size and design, whereas extrinsic cues are attributes such as price and brand that do not exist in physical forms in the product.

However, Miyazaki, Grewal, and Goodstein (2005) argued that consumers of dairy processed milk use intrinsic cues more than extrinsic cues when they formulate evaluations of products in which they are interested. Karaatli and Veryzer (2012) also mentioned that since intrinsic cues provide more predictive value than extrinsic cues, they are recognized as more important cues for dairy processed milk consumers 'product quality judgments. Thus, intrinsic and extrinsic cues are different from each other and have different characteristics and effects. However, no matter which type of cue is used, it is an undeniable fact that both cues are important information for dairy processed milk consumers' product evaluations. For this reason, manufacturers of dairy processed milk should focus on making those two types of cues more attractive and attention getters so that their products can be outstanding among alternatives or competitors.

\section{Empirical Review}

Hong and lee (2005) argue that if responsiveness to complaint appears to be effective and genuine, consumers are more satisfied than they would have been if no complaint had occurred at all. The opportunity for consumers to voice their complaints to a broader public poses new challenges for merchants (Hennig \& Thurau, 2010). Before the era of participatory media, complaints were expressed in one-to-one communication which gave merchants some level of control in terms of recovery strategies. This has changed now as complaints are diffused over the internet (Van Noort \& Willemsen, 2012). This would suggest the importance of getting back to the complaints as fast as possible. An effective complaint handling procedure means that consumers' expectations have been met or exceeded. This will demonstrate to the consumer that the merchant not only cares about the consumer but will take all necessary steps to meet the consumer's expectations (Black \& Kelley, 2009). Effective complaint handling not only improves consumer confidence, but it also helps to build a long-term relationship in business to consumer e-business (Stauss \& Seidel, 2004; tang, 2007).

Huppertz $(2003 ; 2007)$ asserts that resolving problems effectively is likely to influence consumers to make repeat purchases from those merchants. Magnini (2007) also claim this offers an opportunity to convince consumers that the merchants' efforts are genuine. Effective complaint handling is continuing to receive increased attention, in part owing to rising consumer expectations and competitive marketplace responses. Merchants compete in changing market conditions and need to understand the way in which consumers react to transaction failure and how they respond to different approaches of complaint handling (Siddiqui \& Tripathi, 2010).

Knowledge of consumer expectations during complaint handling thus holds important implications for the merchants. Because merchants not only need to know whether they meet, exceed or fall short of consumer expectations, they also need to know which elements of the complaint handling procedure consumers evaluate (Gruber, 2011; Stauss, 2002). When merchants actively listen, provide explanation and note down the problems, these perceptions of complaint efficacy convince consumers that voicing complaints will solve the problems and improve their sense of confidence in online shopping (Susskind, 2005). Consequently, it is crucial that complaint handling procedures 
are forceful and effective, because research has shown that failed complaint handling actions have caused consumer-switching behaviour (Alvarez \& Furst, 2010). In most industries, consumers do not bother complaining (Gruber, 2011; Homburg \& Fürst, 2007) and the absence of complaints is, therefore, not a true indication of effective complaint management. Accessibility involves consumer awareness of the procedure's existence and functioning as well as available options to lodge a complaint that is clearly explained to consumers. The supporting information should be easily accessible in a clear instruction (Volkéry, 2012; Ang \& Buttle, 2012). Conversely, there are consumers who decide not to complain because they do not believe the complaint outcomes would sufficiently compensate the problems due to complicated complaints procedures (Xu \& Yuan, 2009).

Karapetrovic (2006) show in his research of ISO 10002: 2004 that complaints handling procedures need to look beyond the problems that occur instead of merely addressing individual complaints and compensating consumers. In truth, consumer complaints constitute valuable feedback in that they provide opportunities for merchants to understand and to rectify issues occurring in shopping (Luo, 2007). Magnini, (2007) also claim this offers an opportunity to convince consumers that the merchants' efforts are Genuine.

Effective complaint handling is continuing to receive increased attention, in part owing to rising consumer expectations and competitive marketplace responses. Merchants compete in giving the best consumer services, changing market conditions and need to understand the way in which consumers react to transaction failure and how they respond to different approaches of complaint handling (Siddiqui et al, 2010). Knowledge of consumer expectations during complaint handling thus holds important implications for the merchants. Because merchants not only need to know whether they meet, exceed or fall short of consumer expectations, they also need to know which elements of the complaint handling procedure consumers evaluate (Gruber, 2011; Stauss, 2002). For a consumer whose complaints have been resolved amicably, there is likelihood of portraying a positive post purchase behavior. Xu et al, (2009) assert that those consumers' complaint handling procedures and expectations need to be fair and responsive. This is because consumers show higher levels of post-complaint satisfaction than those who perceive the response was sluggish and unfair (Patterson, 2006). Hong et al, (2005) argue that, if responsiveness to complaint appears to be effective and genuine, consumers are more satisfied than they would have been if no complaint had occurred at all. While the general indication is that a consumer is satisfied after being given a positive response to his or her complaints further investigation is needed to establish if the consumer perception has a role in the relationship between the quality driver and satisfaction afterwards. Customer satisfaction cannot be achieved without the fundamental contribution of the customer contact employees who provide the service through solving customer problems in time (Hasan, 2011).

\section{Methodology}

This study was guided by epistemological philosophy. An epistemological issue concerns the question of what is (or should be) regarded as acceptable knowledge in a discipline (Bryman \& Bell, 2011).This study was guided by descriptive cross-sectional research design. (Cooper and Schindler, 2011), posit that research design enables the researcher in the allocation of limited resources by posing crucial choices in methodology. The study used mixed method approach which combine elements of qualitative and quantitative research approaches (Johnson, Onwuegbuzie \& Turner, 2007). The target populations of this study were consumers who purchase dairy milk from 15 major supermarket chains in Nairobi, Nakuru, Eldoret and Mombasa. Specifically the study collected data from consumers who purchase dairy milk from fifteen (15) major 
supermarket chains in Nairobi (KNBS, 2014). The number of consumers who purchase dairy processed milk from the fifteen (15) major supermarkets in Nairobi is estimated to be over two hundred thousand $(200,000)$ consumers per day (KNBS, 2014).

The study collected data from fifteen (15) major supermarkets in Nairobi, Nakuru, Eldoret and Mombasa. Since the number of consumers is more than 10,000 , the sample size was computed using Cochram (1977) formula which gave a sample size of 384 respondents. The respondents were drawn from consumers who buy processed dairy milk from major supermarkets in Nairobi, Nakuru, Eldoret and Mombasa and were selected using simple random sampling. In Kenya, Nairobi is the main market for pasteurized packaged milk, but the large processors are also distributing pasteurized milk to the other main urban centers of Nakuru, Mombasa and Eldoret (Ngurare,2003). Mwatsuma,( 2013) in the study "factors influencing adoption of dairy technologies in Coast province, Kenya" used Cochran formula in getting the sample size. This study adopted a selfadministered, semi-structured questionnaire to get primary data. Yang \& Miller (2008) explain that the questions in a study are directly related to the research questions. The structure of the questionnaires to be used was a 5 point Likert scale. The popularity of open ended questions can be attributed to their usefulness in maintaining uniformity in response categories (Chava \& David, 2009). Newing (2011) states that structured interviews use fixed wording or other stimuli that are presented in exactly the same way to all informants.

Cronbach's alpha was used to test the reliability of the measures in the questionnaires (Cronbach, 1951). This study used construct validity, content validity and criterion validity. Statistical Package for the Social Sciences (SPSS) version 21.0 was used for data entry and data cleaning .Descriptive statistics including measures of central tendency ( mean, median and mode) and dispersion ( variance, standard deviation and range) were calculated to profile the major supermarkets, individual respondents and the study variables. Presentation was done through pie charts, graphs and tables. Multiple regression analysis was used to analyse the relationship between variables. In testing for assumptions of linear regression, linearity test was used. In testing for independence in assumptions of linear regression, independence test was used. In testing for Multicollinearity in the assumptions of linear regression, Multicollinearity test was used. Homoscedasticity was tested for assumptions of linear regression. Homoscedasticity means the relationship under investigation is the same for the entire range of the dependent variable. A hypothesis test is performed on a statement about statistics computed from sample data with the aim of making inferences about the population from which the sample data were drawn. In the study multiple outliers was tested using mahalanobis $D$ - square. Cases with high $D$ - square values were considered to be outliers. Factor analysis was used in identification of the constructs that were then regressed against the dependent variable.

\section{Findings}

A total of 384 questionnaires were given out to consumers of supermarkets chains in Nairobi, Nakuru, Eldoret and Mombasa. A total of 370 out of the 384 questionnaires were filled and returned, giving a response rate of $96.4 \%$. All the questionnaires were correctly filled and were considered adequate for data analysis. This response rate was favourable according to Mugenda and Mugenda (2008) in which they asserted that, a response rate of $50 \%$ is adequate, $60 \%$ good and above $70 \%$ rated very good for analysis. Further, Nordin (2009) in his study on consumers' attitude towards counterfeit products in Malaysia stated that, a response rate of above $70 \%$ is adequate for satisfactory research findings. In addition, Chepkwony, Lagat, Korir, Mambo, and Odera, (2012) in their study on effects of distributive justice complaints resolution strategies on customer satisfaction in Kenya's banking industry achieved a response rate of $97.2 \%$. Finally, Xiao,Ran and Omar (2014) 
in their study on service recovery activities and customer satisfaction achieved a response rate of $97.3 \%$.

Majority of the respondents disagreed that their complaints were handled so well to their expectation ( $M=3.4)$. Majority disagreed that complaints as consumers about the firms products quality were always considered $(M=4)$.Over half of the respondents also disagreed that merchandisers were receptive to their complaints as consumers to their satisfaction $(M=3.9)$. The vast majority of respondents agreed that milk products were replaced in case they were damaged or with defects after sale to consumers $(M=1.9)$.

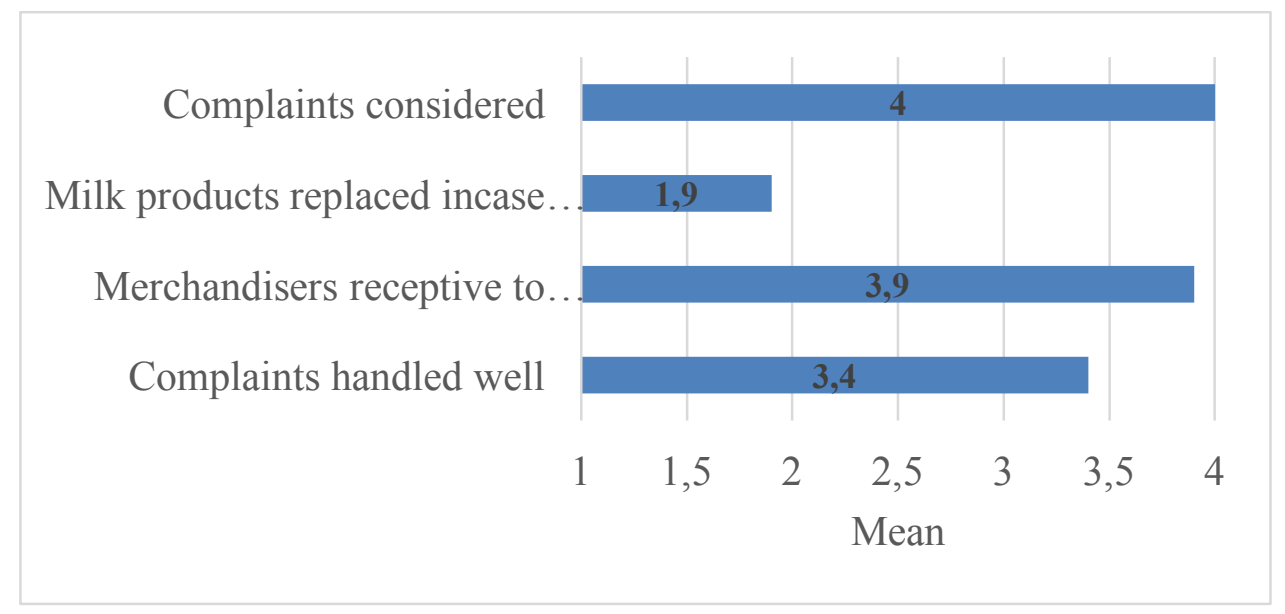

Figure 1: Descriptive Analysis of Consumer Complaints Handling Construct

The vast majority indicated that they were satisfied with their preferred milk processors products $(M=1.46)$. The vast majority of respondents indicated that they were satisfied with the quality of their preferred milk products $(M=1.42)$.Similarly, majority indicated that they spread a positive word of mouth about preferred milk processors products $(M=2.06)$.

Majority of the respondents agreed that they trusted that, their preferred milk product would always be available in the supermarket shelves $(M=1.28)$. Majority of respondents also indicated that their preferred milk processors products are always available to their expectations as a consumer $(M=1.73)$.

The findings show that majority of the respondents indicated that they were satisfied with the supermarket's services $(M=1.66)$. Majority of the respondents agreed that they believed the supermarket offered high quality services to their satisfaction $(M=1.6)$.Over half of the respondents agreed that they trusted that the supermarket handles complaints effectively $(M=3.1)$. 


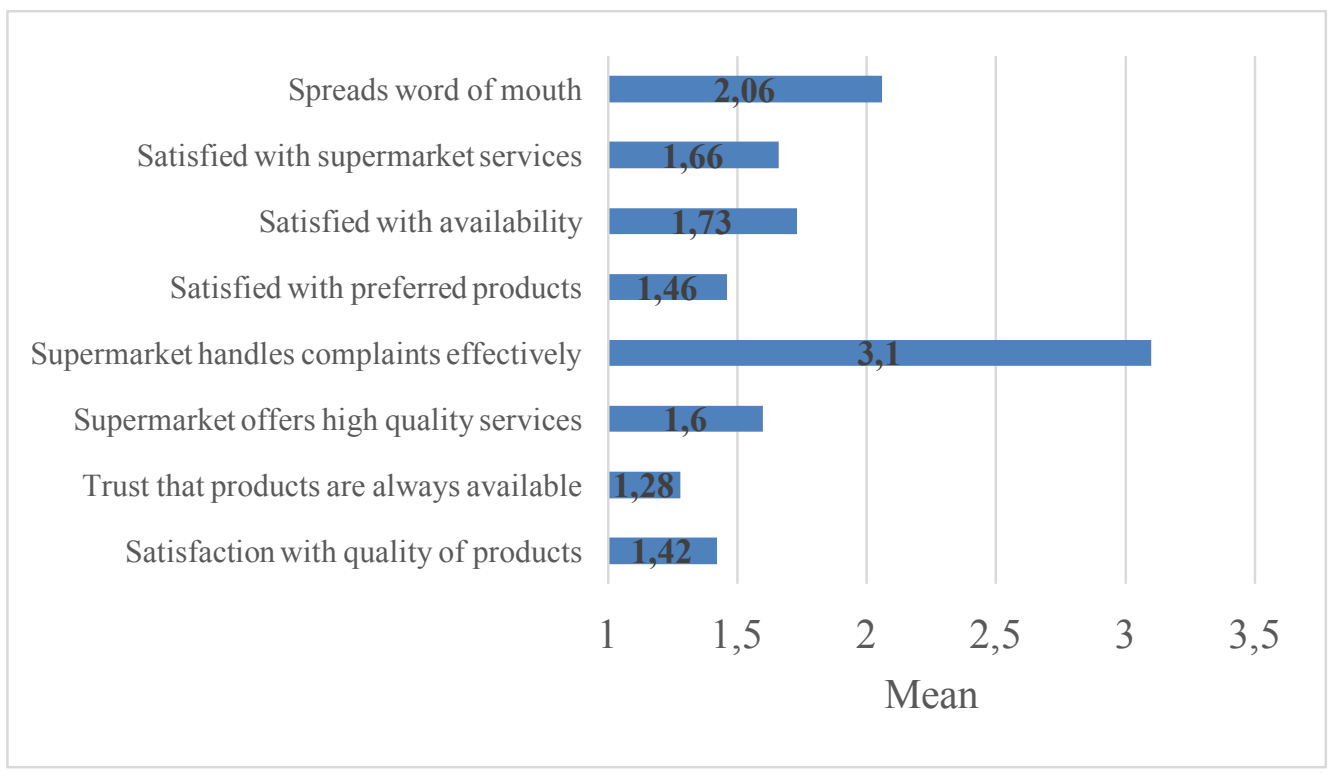

Figure 2: Descriptive Analysis of Consumer satisfaction Construct

The beta value of the computed (composite index) scores of consumers complaints handling is 0.027 with a t-test value of 1.026 and significance level of $\vee \bullet .0 .306$. The hypothesis of no relationship between consumers complaints handling and consumer satisfaction of dairy milk processors in Kenya is therefore retained. This means that there is no statistically significant relationship between computed (collective) consumers complaints handling and consumer satisfaction.

Table 1: Regression Results of Consumers Complaints Handling and Customer Satisfaction

\begin{tabular}{|c|c|c|c|c|c|c|}
\hline \multirow{2}{*}{\multicolumn{2}{|c|}{ Model }} & \multicolumn{2}{|c|}{$\begin{array}{l}\text { Unstandardized } \\
\text { Coefficients }\end{array}$} & $\begin{array}{l}\text { Standardized } \\
\text { Coefficients }\end{array}$ & \multirow[t]{2}{*}{$\mathrm{t}$} & \multirow[t]{2}{*}{ Sig. } \\
\hline & & B & Std. Error & Beta & & \\
\hline \multirow[t]{2}{*}{1} & (Constant) & 3.010 & 0.045 & & 67.244 & 0.00 \\
\hline & $\begin{array}{l}\text { Computed scores of Consumers } \\
\text { complaints handling }\end{array}$ & 0.027 & 0.027 & 0.053 & 1.026 & 0.306 \\
\hline
\end{tabular}

Using the values in Table 1 the new equation for consumers' complaints handling and customer satisfaction is as follows

$Y=3.010+0.027 \mathrm{CCH}+\mathrm{e}$

where $\mathrm{Y}=$ customer satisfaction, $\mathrm{CCH}$ is consumer's complaints handling and $\mathrm{e}=$ error term

The new model shows that without consumer's complaints handling, customer satisfaction would be 3.010. The new model shows that a change in one unit of consumer's complaints handling leads to a 0.027 increase in customer satisfaction. The findings are therefore in disagreement with Blodgett et al (1995) who observed that satisfactory or unsatisfactory handling of complaints determines whether a customer will patronize the seller again or shift his loyalty; and whether that customer will engage in negative or positive evangelism for the service provider. Ateeke and Kalu (2016) also showed that post-complaint satisfaction is significantly influenced by complaint handling through customer-firm interaction, complaining accessibility and compensation policy. In addition the findings are in agreement with Nilsson et al. (2005) that the response to a service fault is normally customer dissatisfaction with the service provider, which may result in a complaint. 
Whether such a complaint is met with an appropriate response or not has a great impact on the customer's perceived satisfaction with the service provided.

\section{Conclusion}

The findings showed that respondents were dissatisfied with consumer complaints handling. Consumers disagreed that their complaints were handled so well to their expectation. The study revealed that merchandisers were not receptive to consumer's complaints to their satisfaction. In addition, consumers' complaints about the firm's products quality were not always considered. The results showed a weak positive relationship between complaints handling and consumer satisfaction. The findings therefore suggest that dairy milk processors in Kenya had poor consumer complaints handling mechanisms. However this seemed to have no reduction in consumer satisfaction in the products in question. This may be attributed to the perceived product quality and high product availability.

The findings showed that respondents were dissatisfied with consumer complaints handling. This may be due to the mechanisms used by processors to handle complaints where the processors relied on untrained supermarket attendants and traditional channels such as mail and telephone. This problem can be solved by having trained agents in supermarkets who would assist consumers in a wide range of issues including receiving complaints. This is a worthwhile investment as the merchandisers can be use to inform consumers of other products, promotions and discounts.

\section{References}

Alauddin, Hossain, M., Ibrahim, Hoque, A. (2015). Perceptions of Consumer Impulse Buying Behavior in the Super Store: A Case Study of Some Selected Super Store in Bangladesh. Asian Social Science, 11 (9), 68-76.

Ajzen, I. (2005). Attitudes, personality, and behavior.New York: Open University Press.

Ajzen, I., \& Fishbein, M. (Eds.). (1980). Understanding attitudes and predicting social behavior. Englewood Cliffs, London: Prentice-Hall.

Akdeniz, B., Calantone, R. J., \& Voorhees, C. M. (2013). Effectiveness of marketing cues onconsumer perceptions of quality: The moderating roles of brand reputation andThirdparty information. Psychology \& Marketing, 30, 76-89.

Alba, J.W.,\& Hutchinson, J.W. (1987).Dimensions of Consumer Expertise.Journal of Consumer Research, 13 (4), 411-54.

Alegre, J.,\&Cladera, M. (2009).Analyzing the effect of satisfaction and previous visits on tourist intentions to return. European Journal of Marketing, 43 (5/6), 670 - 685.

Anderson, E. W., Fornell, C. \& Lehmann, D. R. (1994). Customer satisfaction, market share and portability: findings from Sweden. Journal of Marketing, 58 (2), 112- 122.

Anderson, E.,\& Sullivan, M. (1993). The antecedents and consequences of customer Satisfaction for firms.Marketing Science, 12 (2), 125-143.

Anderson, E.W.,\& Mittal, V. (2000).Strengthening the Satisfaction Profit Chain.Journal of Service Research, 3(2), 107-120.

Aydin, S., Ozer, G.,\&Arasil, O. (2005). Customer loyalty and the effect of switching costs as a moderator variable: A case in the Turkish mobile phone market. Marketing Intelligence and Planning, 23(1), 89-103.

Aydin, S.,\&Özer, G. (2005). The analysis of antecedents of customer loyalty in the Turkish mobile telecommunication market. European Journal ofMarketing, 39(7/8), 910-925.

Babbie, M. (1998). Survey research methods. Belmont; CA:Wadworth publishing. 
Bai, J., Wahl, T. I.,\&McCluskey, J. J. (2008).Fluid milk consumption in urban Qingdao, China. Australian Journal of Agricultural and Resource Economics, 52(2), 133-147.

Bakhshi, S. (2012).Impact of gender on consumer purchase behavior.National Monthly Refereed Journal of Research in Commerce \& Management, 9(1), PP 1-8.

Blodgett, J. G., Wakefield, K. L., \& Barnes, J. H. (1995). The effects of customer service on consumer complaining behaviour. Journal of Services Marketing, 9(4), 31-42.

Brooker, G., Wheatley, J.J., and Chiu, J.S.Y. (1986), The effects of sampling and information onbrand choice when beliefs in quality differences are ambiguous. In: R.J. Lutz (Ed.),Advances inConsumer Research, Vol. XIII, ACR, pp. 272-276.

Brookside Dairy Limited (2014). Website: http://www.brookside.co.ke/bc_about.html

Brown , J.,\& Peter, A.D. ( 1997). The company and the product: Corporate associations and consumer product response. Journal of Marketing, 61(January), PP 68-84.

Brown, G.H. (1993). Brand Loyalty-Fact or Fiction.Advertising Age, 23, PP53-55

Cresswell, J. W. (2011). Designing and Conducting Mixed Methods Research. Los Angeles:Sage.

Cronbach, L. J. (1951). Coefficient Alpha and the Internal Structure of Tests. Psychometrika, 16, PP297-334.

Dabholkar, P. A., Shepherd, C. D., \& Thorpe, D. (2000). A comprehensive framework for service quality: an investigation of critical conceptual and measurement issues through a longitudinal study. Journal of Retailing, 76(2), PP 139-173.

Davis, C. G., Dong, D., Blayney, D. P., \& Owens, A. (2010).An analysis of U.S Household Dairy Demand.ERS Report summary: Economic Research Service.

Deng, Z., Lu,Y., Wei, K. K.,\& Zhang, J. (2009), “Understanding customer satisfaction and loyalty: An empirical study of mobile instant messages in China. International Journal of Information Management, Vol. 30, PP 289-300.

Dimitrades, Z.S., \&Moroudas, T.S. (2007), Demographic Predictors of service satisfaction in Greek Public Organizations.Journal of measuring

Management, 21(2), PP 511-525.

Gatara,T.H.(2010). Introduction to research methodology ( $1^{\text {st }}$ edit). Nairobi; Kenya: Olive Itd.

Ghosh, P., Tripathi, V., \& Kumar, A. (2010). Customer expectations of store attributes: A study of organized retail outlets in India. Journal of retail and leisure property 9(1):75-87.

Graham,S. (2014). An analysis of the dairy industry: Regional impacts and rational price formation. Department of agricultural and resource economics.

Grant, R. M. (2008). A Framework Linking Intangible Resources and Capabilities to Sustainable Competitive Advantage.Strategic Management Journal, 14(8), PP 606-618.

Gray, S. \& Le Heron, R. (2010). Globalising New Zealand: Fonterra Co-operative Group, and shaping the future.New Zealand Geographer, 66, 1-13

Grönroos, C. ( 2007). “Service Management and Marketing: Customer Management in Service Competition",(3rd Edit). England: John Wiley \& Sons Ltd.

Gronroos, C. (2000). Service Management and Marketing: A Customer Relationship Approach. Chichester: Wiley \& Sons.

Gustafsson,A.,Michael,J.,\&Inger, R.(2005). The effects of consumer satisfaction, relationship commitment dimensions and triggers on customer retention.American marketing association, ISSN: 0022-2429.

Hatirli, S. A., Ozkan, B., \&Aktas, A. R. (2004). Factors affecting fluid milk purchasing sources in Turkey. Food Quality and Preference, 15(6), PP 509-515.ISSN 2219-19.

Hausman, A. V., \&Siekpe, J. S. (2009). The effect of web interface features on consumer online purchase intentions. Journal of business research, 62, PP 5-13. 
Hemme, T., Alqaisi, O.A., \&Boelling, D. (2014). IFCN contribution to the IDF/FAO/IFCN joint project, World Mapping of Animal Feeding Systems in the Dairy Sector. International Dairy Federation .

Hemme,T., Bendfeld, H., Hagemann,M. \&Ramanovich, M.(2008). Economic perspectives on climate change. A database for comparison of dairy farming systems in 38 countries. The first IDF dairy farming summit.IFCN Dairy Research Centre, Kiel, Germany.

held in Nairobi, Kenya (27th August 2002), 3.

Kenya Dairy Board. (2014).Activities within the Kenyan Dairy Industry and List of Processors. Nairobi; Kenya: Government of Kenya.

Kenya National Bureau of Statistics (2014).website:http:// www. Knbs.or.ke

Kline ,R. B. (2011). Principles and practice of structural equation modeling ( $3^{\text {rd }}$ ed). New York: The Guilford press.

Kombo, D. K. (2009). Proposal and Thesis Writing: An Introduction. Nairobi: Don Bosco Printing Press.

Kordnaeij, A., Askaripoor,H., \&Bakhshizadeh, A. (2013). Studying affecting factors on customers' attitude toward products with halal brand (Case Study: Kuala Lumpur, Malaysia). International Research Journal of Applied and Basic Sciences, 4(10),PP 3138- 3145.

Kothari, C. R. (2004). Research Methodology: Methods and Techniques (2nd ed.). Oxford:Oxford University Press.

Kothari, C. R. (2009). Research Methodology: Methods and Techniques (5th ed.).New Delhi: New Age.

Kotler, P. (2009). Marketing Management. Toronto: Pearson Ltd.

Kotler, P., \& Armstrong, G. (2008). Principles of Marketing. $\left(12^{\text {th }}\right.$ ed). Englewood cliffs: Prentice hall,inc.

Kotler, P., \& Keller, K.L. (2006).Marketing Management.(12 $2^{\text {th }}$ d). Englewood cliffs: Prentice hall,inc.

Kuikka, A., \&Laukkanen, T. (2012).Brand loyalty and the role of hedonic value.Journal of Product \& Brand Management 21(7): 529-537.

Kumar, A. A., \&Babu, S. (2014). Factors influencing consumer buying behavior with special reference to dairy products in Pondicherry state. International Monthly Refereed Journal of Research In Management \&Technology, 3, PP 65-73.

Kumar, V., \&Bhagwat, Y. (2015) Regaining "lost" customers: the predictive power of first lifetime behavior, the reason for defection, and the

Miyazaki, A. D., Grewal, D., \& Goodstein, R. C. (2005). The effect of multiple extrinsic cues on quality perceptions: A matter of consistency. Journal of Consumer Research, 32, 146-153.

Monirul, I., \&HuiHan,J.( 2012). Perceived quality and attitude toward tea \& coffee by consumers. International Journal of Business Research and Management (IJBRM), 3(3),PP 100-112.

Montazeri, B.,Sharifinia, K.,Hadian, H.,Arabani, M., \&Bazarkhak, S.( 2013). The impact of attitude on consumer behavior. Universal Journal of

Narteh, B. (2003). Service quality in automated teller machines: an empirical investigation.Managing service quality, 23 (1), 62-89.

Nganga, S.K.,Kungu,J., Ridder, N.,\&Herrero,M.(2010). Profit efficiency among Kenyan smallholders milk Producers: A case study of Meru south district Kenya. Journal of agricultural research, Vol.5 pg.332-337

Ngigi, M. (2005).The Case of Smallholder Dairying in Eastern Africa. EPT DiscussionPaper 131, IFPRI, Washington D.C.

Ngigi, M.( 2004).Building on successes in African agriculture.Smallholder dairy in Kenya. International Food Policy Research Institute 
Ngunjiri,W.V.(2011).Smalholder Dairy Production in high altitude Nyandarua Milk-shed inKenya.Status, Challenges and Opportunities.Nairobi:Uon Press

Niezurawski, L. (2006). Determinants of customer satisfaction on the markets of selected dairy products. Polish journal of food and nutrition sciences, 15(56), 155-160.

Njarui D.M.G., M, Nguluu S N, Mwangi D M andKeya G A.(2012) "Challenges in milk processing and marketing among dairies in the semi-arid tropical Kenya", Livestock Research for Rural Development, Vol.22.

Njarui, D. M. G., Gatheru, M., Wambua, J. M., Nguluu, S., Mwangi, D. M. \&Keya, G. A. (2009). Dairy Cattle Value Chain Assessment: Characterization of Milk Production in Semi-Arid Kenya. KASAL Dairy Working Document 1.

Nyariki D. M. \&Thirtle C. (2000). Technical innovation and farm productivity growthin dry land Africa: The effects of structural adjustment on smallholders in Kenya. Agrekon 39(4): 597-606

Nyariki, D. M. (2009). Impacts of policy reforms on the livestock industry in Kenya: The case of the dairy sector. Livestock Research for Rural Development, 21(10), 2009.

Odhiambo,M. (2008).National Livestock Policy, 2008.Sessional Paper No. 2 of 2008.Ministry of Livestock Development, Nairobi:GOK.

Odondi, R. K. (2001). Physical distribution and sales performance: A case of dairy processing firms in Nairobi. Nairobi: University of Nairobi.

Oliver R.L. (2010). "Satisfaction: A behavioral perspective on the consumer", 2nd ed. New York: M.E. Sharpe Inc.

Olson, J.C., \& Jacoby, J. (1972). Cue utilization in the quality perception process. Proceedings of the Third Annual Conference of the Association for Consumer Research, USA, pg167169.

Omore, A., Muriuki, H., Kenyanjui, M., Owango, M.,\&Staal., S.( 1999). The Kenyan dairy subsector.A Rapid Appraisal Report by the MoA-

Park, C. H., \& Kim, Y. G., (2003).Identifying key factors affecting consumer purchase behavior in an online shopping context. International Journal of Retail \& Distribution Management, 31 (1), 16-29.

Patterson, P. G., Cowley, E., \&Prasongsukarn, K. (2006). Service failure recovery: the moderating impact of individual-level cultural value orientation on perceptions of justice. International Journal of Research in Marketing, 23(3), 263-277.

Pearce II, J. A., \& Robinson, R. B. (2011).Strategic Management (12th ed). New York: New York press.

Pornprotang, K., Lockard, D., \&Ngamkroeckjoti,.C.(2013). The impact of corporate social responsibility (CSR) on consumer trust and purchase intention: $A$ case study of condominium development in Bangkok area. International Conference on Business, Economics, and Accounting.

Porter, M.E. (1998). Competitive Strategy, Techniques for analyzing Industries and Competitors, Revised Edition. New York: New York free press.

Radder. L \& Natalie, H. S. (1999). "A Study on milk marketing by selected dairy companies in port elizabeth" . Port Elizabeth. South Africa.

Rahim, R., Jalaludin, F., \&Tajuddin, K.( 2011). The importance of corporate social responsibility on consumer behaviour Malaysia. Asian Academy of Management Journal, 1(16): 119-139.

Rangsan, N., \& N. Titida.( 2014). The effect of dimensions of corporate social responsibility on consumers' buying behavior in Thailand: A case study in Bangkok. International Conference on Economics, Social Sciences and Languages (ICESL'14) May 14-15, 2014 Singapore. 
Razali, N. M \&Wah, Y. B. (2011).Power comparisons of Shapiro- WilkKolmogorovsmirnov, Liliefors\& Anderson- darling tests.Journal of statistical Modeling \& Analytics, 2(1), 21-33.

Sekaran, U., \& Bougie.R. (2010). Research Methods for Business: A Skill-building Approach.Somerset, NJ: John Wiley \& Sons.

Shahzad, K., \&Faryal, N. (2012)" Factors affecting buying behavior of females for purchase of cosmetics" International review of business and social sciences vol. 1, no. 9,pp 68-76.

Young, J., Hooton, N., Muriuki, H., \& Romney, D. (2006).Informal traders lock horns with the formal milk industry: The role of research in pro-poor dairy policy shift in Kenya. Overseas development institute (ODI).

Zairi, M. (200). Managing customer satisfaction: a best practice perspective. The TQM magazine , Vol. 12, no.6, pp. 389-394.

Zikmund, W. \& Babin, G. (2012). Business Research Methods (9th ed.). New York: The Free Press. 